\title{
The Forming Creative Skills in Future Art Teachers in Pedagogical Higher Education Establishments
}

\author{
Prihodin M. D. \\ ORCID https://orcid.org/0000-0002-6891-8585 \\ H.S. Skovoroda Kharkiv National Pedagogical University (Ukraine, Kharkiv)
}

\begin{abstract}
The article covers the process of forming creative skills in future teachers of artistic disciplines in higher pedagogical higher education establishments. At the same time, the cultural orientation of the educational process is emphasized, where the role of the teacher as a subject of the pedagogical process requires the improvement of the system of education and national values on the levels of European standards. Creative skills contribute to the vision of a new, unique, original; cause independent thinking, generating original ideas, content, image forms, creating a harmoniously holistic art piece. The study of artistic disciplines is a specific form of teaching the teacher of fine arts, which in a pedagogical activity is intended to directly form the creative skills of students. At the same time, modern educational realities need to integrate Ukraine into the European educational community. Defined creative abilities as basic, with which you can create a creative product in general, with the subsequent formation of creative skills in the context of the specification on various artistic disciplines (painting, graphics, sculpture, batik, fresco, ceramics and many others). Artistic and aesthetic directions of the phenomenon of "creative skills" are considered in terms of their content, style and forms of image with adequate skills of the student - the future teacher. The creative skills of the teacher combined with the existing optimal pedagogical conditions and pedagogy of teaching artistic educational disciplines, allow us to understand more deeply the dialectical nature of the interdependence between meaningful imagery and forms, image styles in the context of the use of poly-artistic functions of each creative skill during the production of a creative product, an artistic work.
\end{abstract} aesthetics.

Keywords: creativity, craftsmanship, artistic disciplines (visual arts, design), pedagogical culture,

Актуальність дослідження. Вища педагогічна школа відповідальна за розвиток творчого потенціалу нації й формування творчих умінь студентів та підготовки конкурентоспроможніх учителів, i, в тому числі, з художніх дисциплін. Учитель у своїй педагогічній діяльністі реалізує державну політику для створення творчого потенціалу нації, розвитку культури й творчих умінь, формування творчої особистості, серед яких творчі уміння є одними з провідних й визначальних. Творчі уміння сприяють баченню нового, неповторного, оригінального; обумовлюють самостійне мислення, генеруючи оригінальні ідеї, змістовність, форми зображення, створюючи гармонійно-цілісний художній твір. Вивчення художніх дисциплін $\epsilon$ специфічною формою навчання майбутнього вчителя образотворчого мистецтва, який у педагогічній діяльності покликаний безпосередньо формувати творчі уміння учнів. Водночас, сучасні реалії навчання потребують інтегрування України до європейського освітнього 
співтовариства, що обумовлює критичне осмислення й творче застосування в умовах нашої держави, передового зарубіжного досвіду. Через що досліджувана проблема $є$ актуальною й розглядається в аспекті методики формування творчих умінь майбутнього вчителя як творчої особистості нового типу, збагаченої власними творчими вміннями на рівні європейських і світових стандартів.

Аналіз наукових досліджень і публікацій. Художня творчість, творчі уміння в образотворчому мистецтві досліджувались у працях відомих науковців, художниківпедагогів (Є. Антонович, О. Григоренко, Л. Гриневич, В. Даниленко, В. Кремень, Н. Кузьміна， Л. Масол， С. Сисоєва， О. Сова， О. Щолокова， О. Шевнюк та ін.), де зазначається, що вже першокурсник вишу, отримуючи знання, проявляє розуміння в необхідності формування саме власних творчих умінь. Вирішувати творчі завдання зможе педагог, який сам володіє творчими вміннями оскільки «особистість виховує особистість» (К. Ушинський).

Мета статті - висвітлити методику формування творчих умінь майбутніх учителів художніх дисциплін і використання набутих знань, умінь, навичок у професійній педагогічній діяльності. А також визначити такі творчі вміння, які $\epsilon$ базовими для створення будь-якого творчого продукту, відповідно спеціалізації різних художніх дисциплін.

Виклад основного матеріалу дослідження. Методика формування творчих умінь майбутніх учителів образотворчого мистецтва здійснюється в обгрунтованій концепції - «деконструкція» застарілих методів, проведення аналізу та синтезу поліхудожніх функцій кожного творчого вміння, які збагачені художньо-образним змістом і формами зображення, віддзеркалюють їх функціональне призначення (майстерність, образність, цілісність).

На нашу думку, - ия формула аналітичного мистецзтва поєднана 3 художньою інтуїцією, інноваційними технологіями «хай-тек». Майбутній вчитель нового типу - це особистість із всебічно розвинутим інтелектом, яка збагачена власними творчими уміннями в контексті розбудови національної художньої освіти, націлений на відродження української ментальності [3]. 
Наголосимо, що художній твір відрізняється від технічного - реальним зображенням дійсності в художніх образах із психологічним настроєм $[6 ; 7 ; 8 ; 9 ; 10 ; 11$; 12], чого технічний проект не передбачає.

Н Кузьміна у творчому мисленні педагога, як творчої особистості, виділяє гострий розум, винахідливість, критичність і вважає однією 3 причин невдачі у педагогічній діяльності «рабське слідування обраному стандарту» [2, с. 83]. До того ж, у будь-якому творі — літературному, музичному і художньому має бути присутній композиційний задум і порядок побудови. Щось повинно бути головним, а інше другорядним, що підпорядковане головному. Якщо цього не буде, твір розпадеться на окремі, нічим не пов’язані самостійні частини. Тому, «...цілісності твору вже не існуватиме», — підкреслює професор В. Даниленко [1, с 151]. У національній доктрині розвитку освіти України обумовлено завдання щодо створення оптимальних педагогічних умов.

Перша педагогічна умова: формування творчих умінь — це наявність у студента нестандартного мислення, системи певних знань, навичок, а також розвиненої структури психологічних компонентів: інтуїції, уяви, фантазії.

Друга педагогічна умова — цілеспрямоване формування творчих умінь кожної особистості, здатності діяти в інтегральному культурологічному спрямуванні, спілкування мистецькою мовою, оперуючи їх художніми образами, що включає три основних компоненти: аналіз через синтез, нестандартне вирішення, рефлексія й оцінювання власних творчих умінь.

Третя педагогічна умова формування творчих умінь — національний менталітет з європейським світоглядом на цінності, творча особистість.

Оптимальні педагогічні умови формування творчих умінь вчителя - це організаційна форма навчально-виховного процесу за таких вимог:

• стійкий моральний та фізичний стан як викладача, так і студента;

• належне науково-методичне й матеріальне забезпечення;

- творча співпраця викладача зі студентами й студентів між собою;

- самостійна творча робота, самовдосконалення, самооцінка;

- проведення «майстер-класів», експериментів, наукових досліджень;

• участь у конкурсах, художніх виставках, міжнародних олімпіадах. 
Отже, створені оптимальні педагогічні умови забезпечують підготовку творчої особистості й конкурентоспроможного вчителя на ринку праці.

Разом з тим необхідно створювати плідний грунт для дистанційного навчання, самостійного творчого мислення, де викладач повинен творчо підходити до методичної допомоги кожному студенту, особливостям психічного й морального його стану та вирішення суперечностей.

А далі студентські роботи необхідно представляти на різних конкурсах, художніх виставках, як найбільш результативні в плані творчих умінь.

Наведемо висловлювання науковцями розуміння творчих умінь.

Для навчально-виховного процесу, а також виконання навчальних і творчих завдань студентами, визначним науковцем, педагогом С. Сисоєвою запропоновані такі творчі вміння: 1) проблемне бачення - уміння усвідомити і побачити проблему; 2) здатність до висування гіпотез, оригінальних ідей, за допомогою яких на підставі фактів робиться висновок про об’єкти, явища, їх розвиток; 3) уміння аналізувати, інтегрувати та синтезувати інформацію - вміння розділяти ціле на частини, поєднувати частини в єдине ціле, знаходити логічні взаємозв’язки між окремими частинами цілого; 4) здатність до виявлення протиріч - здатність бачити діалектичне протиріччя; 5) здатність до дослідницької діяльності; 6) розвинуте уявлення, фантазія; 7) здатність до міжособистісного спілкування; 8) уміння довести почату справу до кінця; 9) уміння встановлювати причинно-наслідкові зв'язки, приховані взаємодії [4, с. 73-74].

Дослідження, проведене I. Баришніковою, дозволило виявити особливості специфіки формування творчих умінь, сприймання й розуміння архітектури:

1) уміння правильно оцінювати співвідношення частин і цілого; 2) уміння уявно оперувати образом у просторі; 3) уміння правильно оцінювати та передавати в малюнку або макеті обсяг і положення будинку в просторі.

Тож, проводячи наукові дослідження методики формування творчих умінь майбутнього вчителя образотворчого мистецтва в процесі навчання художніх дисциплін, нами сформовані власні базові творчі вміння із урахуванням змістовнообразних поліхудожніх функцій для виконання навчальних завдань й творчого продукту, а також завдяки яким, здійснюється професійно-педагогічна діяльність: 
1. Уміння визначати головне й другорядне, опановуючи художню майстерність, відображаючи дійсність у художніх виразних образах.

2. Уміння проводити аналіз і синтез, відтворюючи характери, емоції персонажів або стан природи в контексті гармонійної цілісності твору.

3. Уміння пропонувати гіпотези, нестандартні оригінальні ідеї, винаходи, поєднуючи художню інтуїцію з аналітичним мистецтвом.

4. Уміння співпрацювати в системі «студент-викладач», розв’язуючи об'єктивно суперечності і рефлексію самооцінки власних творчих умінь.

5. Уміння трансформувати природні біонічні форми в змістовні художньообразні зображення, проводячи експериментальні дослідження.

6. Уміння застосовувати комп’ютерні технології: «Color Painter», «Adobe Photoshop», виготовляючи екологічний й енергозберігаючий продукт відповідно до вимог євростандартів.

7. Уміння проводити експерименти та науково-дослідницьку діяльність.

Висновки. Отже, обравши художньо-педагогічну діяльність майбутнього вчителя образотворчого мистецтва, нами було визначено ті творчі вміння, які $\epsilon$ поліхудожними, ефективними ц̆ універсальними. Вони можуть використовуватись як базові творчі вміння відповідно спеціалізації з різних художніх дисциплін: живопис, скульптура, розпис, кераміка, батик, вишивка, макраме тощо.

Творчі уміння вчитель реалізує в педагогічній діяльності, допомагає формувати творчі уміння школярів під час виконання самостійних класних завдань i, загалом, творчого продукту.

\section{References}

1. Danilenko V.I. Dizain : pidruchnyk [Design]. Harkiv: HDADM, 2003. 320 c.

2. Kuzmina N.V. Professionalism lichnosti prepodavatelya I mastera proizvodstvennogo obucheniya / [Professionality of teacher's and master's of craft education personality]. Moskva: Vysh. shk., 1990.

3. Programa rozvytku vishoi osvity Ukrainy «Osnovni zasady rozvytku vishoi osvity Ukrainy» [Development of higher education in Ukraine The main features of development of higher education of Ukraine]. Kyiv. 2008. Ch.4.

4. Sysoeva S.O. Osnovy pedagogichnoi tvorchostil [Basics of pedagogical art]: pidruchnyk. - Kyiv: Millenium, 2006. - 344 c. 
5. Ukrainskyi sovetskiy enciclopedycheskyi slovar: v 3-h t./ [Redcol.: A.V. Kudrickiy (otv. red.) i dr.]. [Ukrainian soviet encyclopedic dictionary]. Kyiv: Glav. Red. USE, 1989. 772 .

6. Grigorenko Victoria, Matviienko Olena. The peculiarities in formation senior preschool children's attitude toward Arts and Crafts. Intellectual Archive. Toronto : Shiny Word.Corp. (Canada). 2017. March/April. Vol. 6. No. 2. PP. 83-91.

7. Pet'ko L.V. Brainstorming and the formation of professionally oriented foreign language teaching environment in the conditions of university (for the specialties 023 «Fine Arts» and 022 «Design»). Economics, management, law: challenges and prospects: Collection of scientific articles. Psychology. Pedagogy and Education. - Discovery Publishing House Pvt. Ltd., New Delhi, India. 2016. P. 214-217.

8. Pet'ko L.V. Development of students' cognitive activity in foreign language teaching by using analogy method. Actual problems of globalization: Collection of scientific articles. - Midas S.A., Thessaloniki, Greece, 2016. P. 232-237.

9. Pet'ko Lyudmila. Developing students' creativity in conditions of university. Research: tendencies and prospects: Collection of scientific articles. - Editorial Arane, S.A. de C.V., Mexico City, Mexico, 2017. - P. 272-276.

10. Pet'ko L.V. Formation of professionally oriented foreign language teaching environment in the conditions of university for students of art specialties. Economics, management, law: problems of establishing and transformation: Collection of scientific articles. - Al-Ghurair Printing \& Publishing LLC, Dubai, UAE, 2016. P. 395- 398.

11. Shevniuk O. Axiological Approach in Professional Preparation of Future Teachers of Fine Arts. Cultura - Sztuka - Edukacja. Tom 1. Krakow: Wydawnictwo naukowe universytetu pedagogicznego, 2015. P. 374-381.

12. Sova Olga. The essence and content of artistic-pedagogical skills in future teachers of Fine arts. Intellectual Archive. - Toronto: Shiny Word.Corp. (Canada). 2017. (March/April). Vol. 6. No. 6. PP. 66-79.

Translation of the Title, Abstract and References to the Author's Language

\section{УДК 378.016:7}

Пригодін М.Д. Формування творчих вмінь майбутніх вчителів художніх дисциплін у педагогічних закладах вищої освіти.

Висвітлено процес формування творчих умінь майбутнього вчителя художніх дисциплін у педагогічних навчальних закладах освіти. Разом з тим підкреслюється культурологічна спрямованість навчального процесу, де роль учителя, як суб'єкта педагогічного процесу, потребує вдосконалення системи освіти і утвердження національних цінностей на рівні європейських стандартів. Визначено базові творчі уміння, за допомогою яких можна створювати в цілому творчий продукт з подальшою художньою доробкою відносно специфіки даного виду мистецтва. Розглянуто художньо-естетичні напрями феномена «творчі уміння» в плані їх змістовності 3 адекватною майстерністю студента, майбутнього вчителя, його творчі пошуки, поєднані з наявними оптимальними педагогічними умовами і викладанням художніх 
навчальних дисциплін, що дозволяють глибше усвідомити діалектичний характер взаємозалежності змісту сформованих творчих умінь і професійності виконавця в особі вчителя.

Ключові слова: творчі уміння, майстерність, художні дисципліни (образотворче мистецтво, дизайн), педагогічна культура, естетика.

\section{Лimepamypa}

1. Даниленко В.Я. Дизайн: підручник. Харків: ХДАДМ, 2003. 320 с.

2. Кузьмина Н.В. Профессионализм личности преподавателя и мастера производственного обучения. Москва: Высш. шк., 1990.

3. Програма розвитку вищої освіти України «Основні засади розвитку вищої освіти України» [ Текст]. Київ 2008. Ч.4. $344 \mathrm{c}$.

4. Сисоєва С.О. Основи педагогічної творчості: підручник. Київ: Міленіум, 2006.

5. Украинский советский энциклопедический словарь: в 3-х т. / [Редкол.: А.В.Кудрицкий (отв. ред.) и др.]. Киев: Глав. ред. УСЭ, 1989. 772 с.: ил.

6. Grigorenko Victoria, Matviienko Olena. The peculiarities in formation senior preschool children's attitude toward Arts and Crafts. Intellectual Archive. Toronto : Shiny Word.Corp. (Canada). 2017. March/April. Vol. 6. No. 2. PP. 83-91.

7. Pet'ko L.V. Brainstorming and the formation of professionally oriented foreign language teaching environment in the conditions of university (for the specialties 023 «Fine Arts» and 022 «Design»). Economics, management, law: challenges and prospects: Collection of scientific articles. Psychology. Pedagogy and Education. - Discovery Publishing House Pvt. Ltd., New Delhi, India. 2016. P. 214-217.

8. Pet'ko L.V. Development of students' cognitive activity in foreign language teaching by using analogy method. Actual problems of globalization: Collection of scientific articles. - Midas S.A., Thessaloniki, Greece, 2016. P. 232-237.

9. Pet'ko Lyudmila. Developing students' creativity in conditions of university. Research: tendencies and prospects: Collection of scientific articles. - Editorial Arane, S.A. de C.V., Mexico City, Mexico, 2017. - P. 272-276.

10. Pet'ko L.V. Formation of professionally oriented foreign language teaching environment in the conditions of university for students of art specialties. Economics, management, law: problems of establishing and transformation: Collection of scientific articles. - Al-Ghurair Printing \& Publishing LLC, Dubai, UAE, 2016. - P. 395- 398.

11. Shevniuk O. Axiological Approach in Professional Preparation of Future Teachers of Fine Arts. Cultura - Sztuka - Edukacja. Tom 1. Krakow: Wydawnictwo naukowe universytetu pedagogicznego, 2015. P. 374-381.

12. Sova Olga. The essence and content of artistic-pedagogical skills in future teachers of Fine arts. Intellectual Archive. - Toronto: Shiny Word.Corp. (Canada). 2017. (March/April). Vol. 6. No. 6. PP. 66-79. 